Keith M. Carlson

Keith $M$. Cartson is an assistant vice president at the Federal Reserve Bank of St Louis. Thomas A. Pollmann provided research assistance.

\title{
How Much Lower Can the Unemployment Rate Go?
}

N JUNE 1988, the civilian unemployment rate dipped to 5.3 percent, its lowest rate since May 1974. The Council of Economic Advisers (CEA), in its 1988 Annual Report, forecast a continuing drop in the unemployment rate, accompanied by a decline in the inflation rate from 4.6 percent in 1987 to 3 percent in $1991 .^{.}$

These developments raise an interesting question: how low can the unemployment rate be driven without accelerating inflation? In the late 1970 s, considerable research was devoted to the discussion of such a critical rate, usually referred to as the "natural rate of unemployment." This research produced estimates of the natural rate in the late 1970 s ranging between 5 percent and 7 percent but generally were centered on 6 percent. ${ }^{2}$ With the unemployment rate well above 6 percent for most of the $1980-87$ period, the debate about the level of the natural rate had subsided; with the unemployment rate moving well below 6 percent in early 1988 , however, the debate has now resurfaced.
This article reviews the factors that determine the natural rate of unemployment, focusing specifically on developments since 1979. First, it dis cusses the concept of unemployment and summarizes how the government measures unemployment. Second, it reviews the choice of benchmark years as an aid in the analysis. Finally, it examines the underlying determinants of the natural rate of unemployment in detail. Though no attempt has been made to derive precise estimates of the natural rate, the direction of its movement in recent years has been detailed."

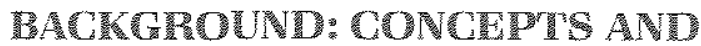 MEASUPWMERT}

To analyze recent unemployment trends, it is useful to summarize the reasons for unemployment. Since the focus is on unemployment as measured by the U.S. govermment, some detail about how unemployment statistics are gathered is also useful tsee opposite page).
The CEA report was prepared in February. See Council of Economic Advisers (1988), p. 50. For further detail on the Administration's forecast, see Office of Management and Budget (1988), pp. $3 b-7-8$. The annual inflation rate is that for consumer prices measured from fourth quarter to fourth quarter.

${ }^{2} \mathrm{~A}$ representative estimate is that of Cagan (1979), p. 215. For a more exhaustive survey of alternative estimates, see Weiner (1986).
Most of the studies were done in the late 1970 s and have not been updated since then. See Weiner (1986). The major exceptions are Rissman (1986) and Gordon (1987), in which he "assumes" continuation of the natural rate at 6 percent through 1985. He offers statistical evidence in support of this contention in Gordon (1988). 


\section{A Primer on U.S. Unemployment Statistics}

Wadt month, daring he weet ecutathing the 12 m day of he nonin lhe Us Bureat of the Census s117eys 65,000 households for the But reav of labor Statisties one formth of the house holds is replaced each houth so hat ho Gousehold is milemiewed mone that $104 \mathrm{H}$ months in a row this prosedine allows for

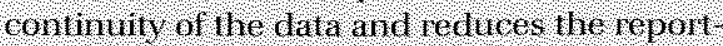
ing burden on fanilies.

Th wes ponse to a series of questions. Whe mier? viewer derermines whether each household member 16 years and older is emploved hnem. jloyed or not in the labor fored, themploved persons are those who had ho enploy ment

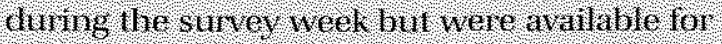
wolk the inter wewer also estathlishes whether

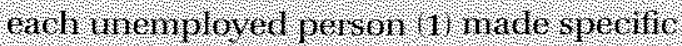
efroms to find work in the preceding tow weeks. 2) was waiting to be rectlled 10 a ob hon which he wi she had been lard on or 3 l was wailing to regort to a new fol g with in 30 days.

Jumt her inom mation is oblamed about the

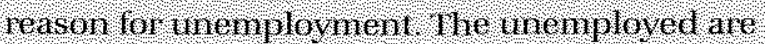

For a usetul sumnary or how the government colects intornation for ts unemploynent rebort, see bureau of Labor Statistics (1987)

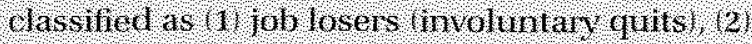
Tob leavers rolumtay quils, 8 , reentrants Mhose who premensly worked hul were out of the labor lor ce before looking for work, and 4 now entirnts Ihose who never worked before but were rom $160 \mathrm{king}$ for worls?

Tuployed persons are 11 persens who, dint ing the survey week, enther worked as pald ent plojees in their own busness or as whpaid Workers in a tanily operated enterpmise, and 2 Mhose who did hot work bur had jobs from Which they were temporarly absent begalse of

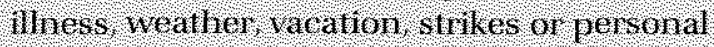
reasons:

the labor foree is the stint of persons aged 16 and ower win are dassified as emploved or unenploved, the unemuployment rate is callo

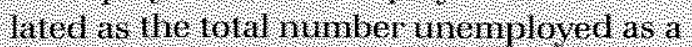
percent of the labor foree Unemplounchl rates according 10 sex, age race and reason for in enplomment are also ealculated.

The govennent also provides ntormation on the distinction befween part tine and fult: ime employment.

\section{Thes of Unemplowment}

Unemployment can be categorized as frictional, cyclical and structural. Although the government does not present its statistics in this way, such a categorization is still helpful in understanding why unemployment occurs.

Cyclical unemployment can be most readily understood as representing movements of the unemployment rate that result from fluctuations of aggregate demand for goods and services. These fuctuations, in tum, can be traced to monetary and fiscal policy or anything else that affects aggregate demand.

Frictional unemployment results from relative shifts in the supply or demand for goods and services between industries of occupations. Because information about jobs is costly to obtain, people can be "caught between jobs:" resulting in tempo- rary unemployment while information about other jobs is sought. Sometimes, to emphasize its shortrun transitional nature, this type of unemploy ment is called turnover unemployment and is considered a vital aspect of the operation of a freem enterprise economy.

Structural unemployment occurs when there is a mismatch of workers and job vacancies either by reason of skill or location. It is only artificially distinguishable from frictional unemployment in that it is considered longer in duration and involves, in addition to the costs of job-information search, training $\mathrm{Or}^{2}$ relocation costs.

Categorizing unemployment into three types is a useful way to analyze it. The three ypes of unemployment involve costs in obtaining information about the avalability of other jobs. Because labor markets are characterized by heterogeneity of skils and job requirements, it lakes time and 
resources to get such information. In general, this process continues until the expected benefit of the search (present value of expected future incomef equals the cost of the continued search (again, in present value tems).

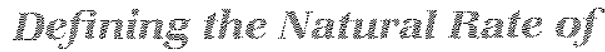 thentolowment}

To analyze unemployment further, one must clarify the meaning of the term "natual tate of unemployment." This can be done by explaining the concept using a Phillips curve diagram.

Phillips-curve analysis was popularized in the 1960 s and is still useful foday as an expository device." In essence, the Phillips curve summarizes the relationship between inflation and the unemployment rate. When first introduced, it was thought to be a reationship that policymakers could exploit. Over the years, however, this interpretation has changed. Analysts now generally accept that there is a whole family of short-run Phillips curves, comesponding to different expected rates of inflation ( $\dot{P}^{*}$ in figure 1$)$.

\section{Figure 1}

\section{Phillips Curve Diagram}

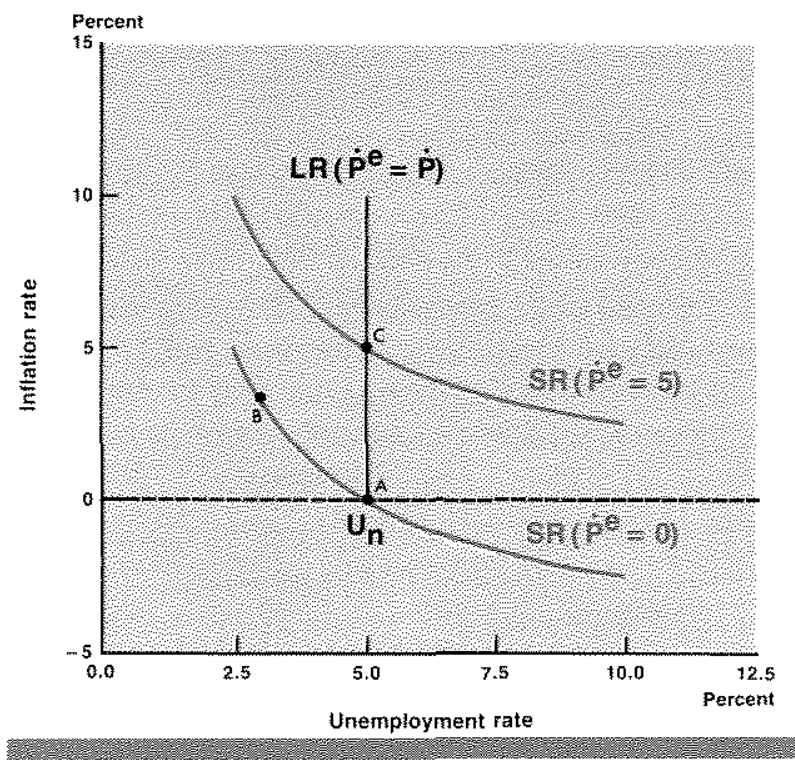

In the short run, before expectations of inflation change, there is a trade-off between inflation and unemployment (shown as SR curves in ligure 1). Suppose the economy initially is at point $A$, with expected inflation equal to zero. If monetary and fiscal policy become expansionary, employens will note an increase in sales and will interpret the increase as a shift in demand for their product and attempt to expand employment. Attractive wage offers will induce many workers to cut short their job search and accept employment. Higher prices and lower unemployment will result, noving the economy to point $B$.

This movement is temporary, however, as both employers and workers come to expect inflation. When the shift in demand is perceived as general, workers will return to their normal job search patterns and employers' demand for labor will be reduced to previous levels. The economy will

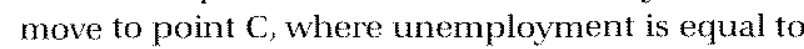
its natural rate, $U_{i}$, once again, but inflation is higher than it was at point $A$, The vertical line is called a long-run Phillips cure because it reflects a period long enough for inflationary expectations to adjust fully.

The revised interpretation of the Phillips curve yields a definition of the natural rate of unemployment: when the actual rate of inflation equals the expected rate, the unemployment rate that corresponds is the natural rate (shown as $U_{1}$ in figure 1 ). This does not mean that there is anything "natural" about such a rate. For example, it is not constant over time, but rather is influenced by demographic changes as well as govemment policies.

The Phillips cuve diagram also allows a more precise definition of cyclical unemployment. When unemployment departs from its natural rate, we have cyclical unemployment. Or, in other words, cyclical unemployment results when acfual inflation and expected infation are unequal.

The government's unemployment statistics provide little help in estimating the natural rate. Conceptually, however, the sum of frictional and structural unemployment is equal to natural unemployment. Consequently, any factor that influences either frictional or structural unemploy" ment (or both! is relevant to the determination of the natural rate.

Past research suggests that the most important influences on the naturat rate are demographic or institutionat. Demographic factors involve such characteristics of the work force as age, sex and racial distriblention. One of the most prominent demographic factors in the post-word War II period occured when the baby-boom generation came of age and entered the labor market. In recent years, this generation has swelled the size of 


\section{Chart 1}

\section{Inflation and Unemployment Rates}

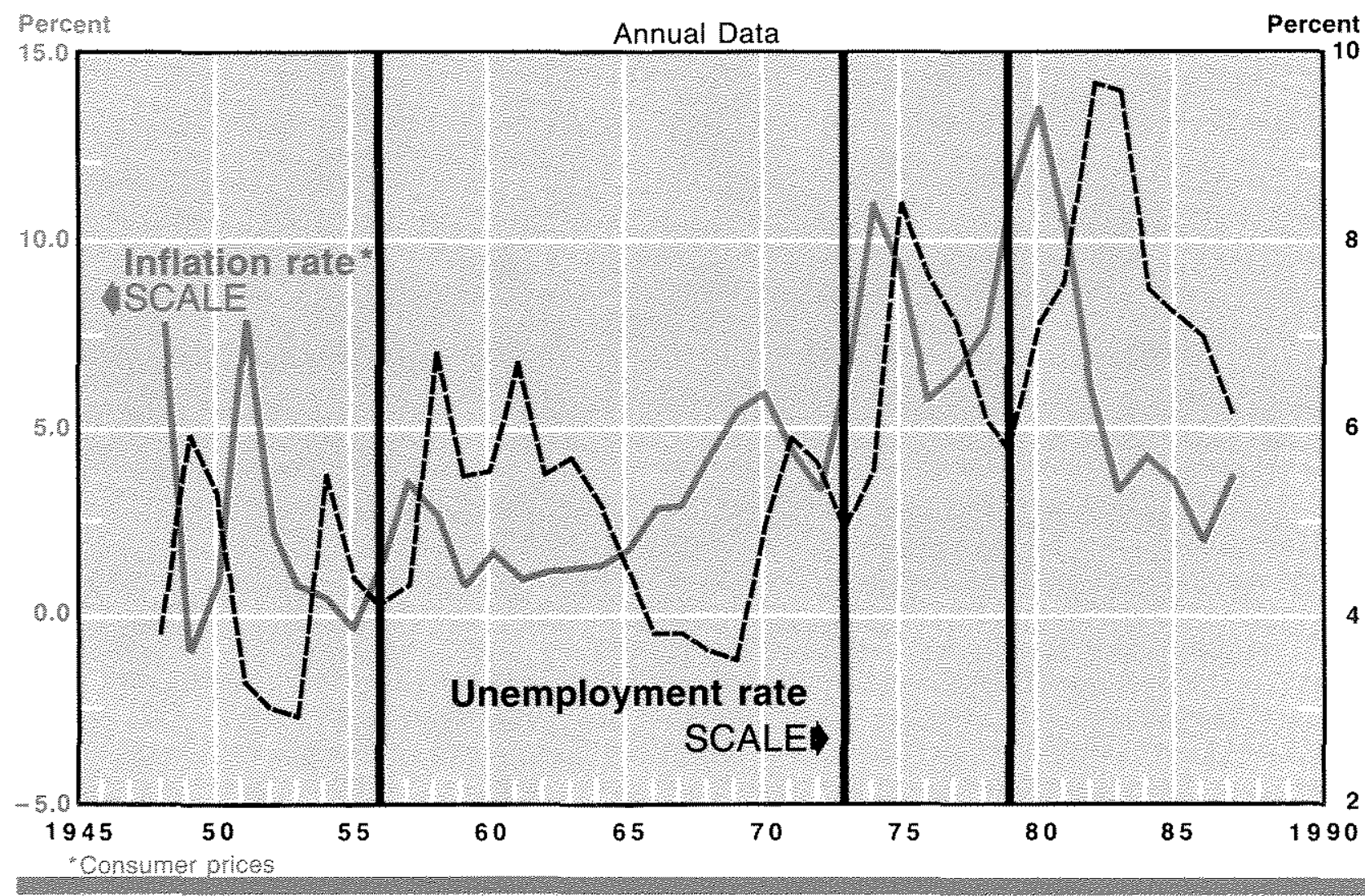

the prime age working group lage 25 to 54 . Age groups like this require time to develop the skills necessary to match the requirements of job vacancies. Such adjustments eventually take place, but the process is usually longer than, say, the temporary nature of tumover or even cyclical unemployment.

Institutional factors can have an effect on the natural rate, for example, the pattern of shifting demand across industries, the minimum wage, and government policies that influence jobinformation search (personal and employer taxes, unemployment benefits.

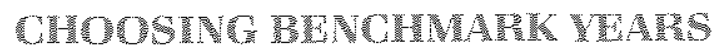

To analyze unemployment trends, one must begin with the choice of certain benchmark vears that are representative of full employment. The benchmark years in this study are ones that occur late in business expansions and are free of the influences of war. It is difficult to identify any years in the $1948-55$ period as benchmat years: they are obviously influenced by the economic conditions associated with World War ll, the Korean War and their aftermath. For this reason, 1956 is chosen as the first benchmark year. This year is recognized generally as one of "full employment" without serious inflation and the other benchmark years chosen -1973 and $197^{9}$-... are also ones that occur late in business expansions and are generally free of wartime influence."

Chart 1 summarizes inflation and unemploym ment, with the benchmark years highlighted. As one can see, the relationship between the two is highly variable, reflecting a host of complex factors. A direct examination of the inflation-
${ }_{5}$ "Full employment" is defined here as the employment counterpart of the natural rate of unemployment.

"This was probabfy recognized first by the Council of Economic
Advisers in the early 1960 s. Actually both 1955 and 1956 are used; de Leeuw and Holloway (1983) use 1955, while Cagan (1979) uses 1956. 


\section{Chart 2}

\section{Unemployment Rates}

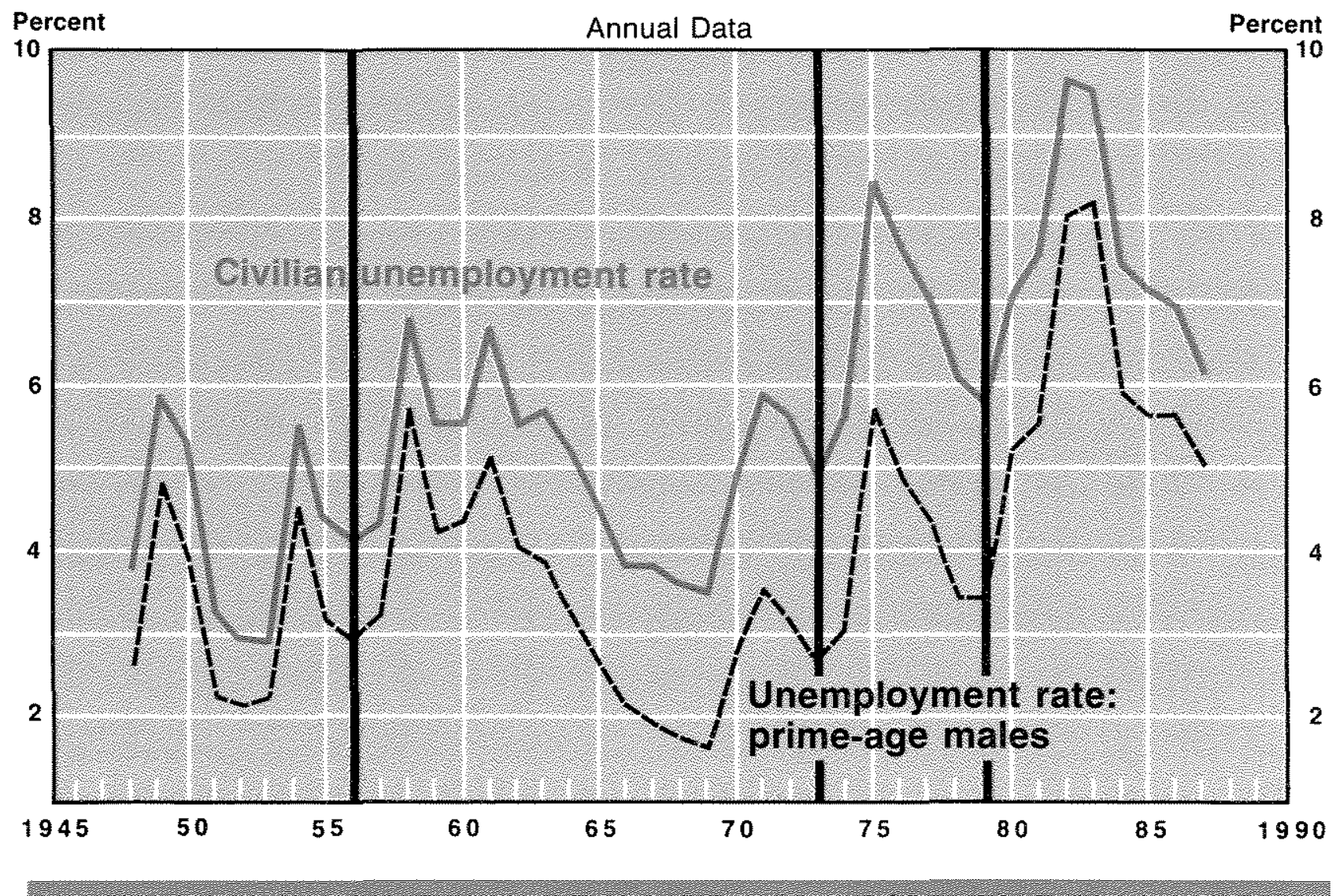

unemployment relationship yields little information about how low the unemployment rate can go.

Chart 2 summarizes the civilian unemployment rate along with that for prime-age males for the 1948-87 period. Civilian unemployment in the three benchmark years ranges fiom 4.1 percent of the labor force in 1956 to 5.8 percent in 1979 . Compared with 1979 , it appears that the economy reached full emplovment in late 1987 when the unemployment rate fell below 6 percent; conpared with the earlier benchmarks, however, there seems to be room for further employment expansion.

The structure of unemployment, especially as it reflects a changing composition of the labor force, is an additional consideration in assessing the nearness of actual employment to full employment. Chart 2 also shows unemployment for prime-age males, the group that has the lowest tumover rate in the labor force. The unemploy- ment rate for this group was 2.9 percent in 1956 , 2.6 percent in 1973 , and a somewhat higher 3.4 percent in 1979. The 1987 unemployment rate for this group averaged 5 percent, again suggesting there is room for further expansion in employment.

A direct examination of those unemployment measures that are considered most important does not provide a clear-cut conclusion about whether the 1987 levels of unemployment indicate an economy approaching full employment. Therefore, we examine the composition of the labor force in further detail.

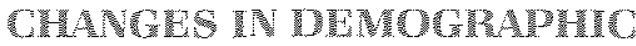 FACOTPS}

The overall unemployment rate reflects a weighted average of many unemployment rates, as table 1 indicates. As this table shows clearly, certain groups typically have higher or lower unem- 


\section{Table 1}

\section{Unemployment Rate by Age and Sex (selected years)}

\begin{tabular}{lll}
\hline \\
\hline
\end{tabular}

ployment rates than the overall average. The teenage group is always the highest, followed by the 20-24 year-old group. Consequently, to understand more fully the significance of a given unemployment rate, one must examine both the relative importance of each age group in any given year and the growth rate of each age group over time.

Table 2 summarizes the relative importance of the different age-sex groups for the benchmark years. One striking observation is the change in the ratio of males to females that has taken place since 1956 . This changing proportion, however, may not be critical in interpreting what has happened to the overall unemployment rate: as table 1 shows, female unemployment is not always above that for males.?

What is important in interpreting movements in the unemployment rate over time is the shifting importance of age groups. Obviously, the rise in importance of the 16-19 and $20-24$ year-old groups from 1956 to 1979 was an important factor in interpreting unemployment trends for that period. As table 1 shows, the unemployment rate was always highest for these groups. Significantly, however, these youngest age groups have declined as a proportion of the labor force from 1979 to 1987.

Table 3 summarizes the growth of the labor: force by age group between the benchmark years.
Table 2

Composition of Labor Force by Age and Sex (selected years)

\begin{tabular}{|c|c|c|c|c|}
\hline & 1950 & 1970 & 1979 & 4087 \\
\hline $0 t a t$ & $1001 \%$ & $3000 \%$ & $14061 \%$ & $1000 \%$ \\
\hline 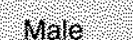 & $67 \%$ & 610 & 579 & 552 \\
\hline 4,1640 & 3 & 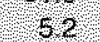 & 449 & 34 \\
\hline 2024 & 52 & 80 & 81 & 65 \\
\hline 2654 & 456 & 378 & 361 & 97.9 \\
\hline 55,64 & 98 & 799 & 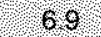 & 58 \\
\hline 65 & 439 & $2 \longdiv { 1 }$ & 19 & 186 \\
\hline renvale & 322 & 30, & 42, & 447 \\
\hline 416 - 9 & 48 & 4,3 & 443 & 32 \\
\hline $20-24$ & 8,7 & 6.3 & 69 & 60 \\
\hline $25-54$ & 20.6 & 224 & 253 & 804 \\
\hline 55,64 & 130 & $14 \%$ & 44 & 14 \\
\hline $65 \%$ & 142 & 122 & 14 & 10. \\
\hline
\end{tabular}

Way hot equal 100 due to rounding.

Table 3

Growth of Labor Force by Age and Sex (selected years, annual rates)

\begin{tabular}{|c|c|c|c|}
\hline & $1956 / 70$ & 197379 & 197987 \\
\hline Toial & 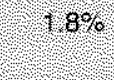 & $27 \%$ & $17 \%$ \\
\hline $101 \mathrm{te}$. & & & \\
\hline 1416 & 39 & 15 & 27 \\
\hline $20 \cdot 24$ & 43 & 29 & 11.1 \\
\hline 25.54 & 0.6 & 1.9 & 23 \\
\hline $55-64$ & 07 & 04 & 0.5 \\
\hline $65 \%$ & 14, & 0.3 & 0.0 \\
\hline Fenale & & & \\
\hline $16-19$ & 4.3 & 29 & 10 \\
\hline $20-24$ & 30 & 42 & 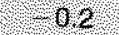 \\
\hline 25,84 & 23 & 4.8 & 40. \\
\hline $55-64$ & 29 & 1,8 & 0.6 \\
\hline 654 & 15 & 145 & 06 \\
\hline
\end{tabular}

For the $1979-87$ period, the $25-54$ year-old group grew fastest, reflecting the maturation of the $16-19$ and $20-24$ year-old groups of the $1970 \mathrm{~s}$.

To aid in analyzing the effects of changes in the underlying demographics, a weighted unemployment rate, where the weights are based on the composition of the labor force, is commonly used.s

See Clark (1977), Flaim (1979), Cain (1979), Antos, Mellow and Triplett (1979) and Cagan (1979). 
Table 4

Alternative Unemployment Rates

\begin{tabular}{|c|c|c|c|c|c|}
\hline & Overall nate & Fred Weight & Prime-Age & $\begin{array}{l}\text { Overall Less } \\
\text { Fired-Weight }\end{array}$ & $\begin{array}{l}\text { Overall Less } \\
\text { Prime-Age Male }\end{array}$ \\
\hline 1950 & $4 \%$ & $43 \%$ & $2.9 \%$ & $402 \%$ & 12 \\
\hline 1973 & 49 & 44 & 26 & 0.5 & 23 \\
\hline 1979 & 59 & 53 & 34 & 0.6 & 25 \\
\hline 1980 & 72 & 66 & 52 & 0.6 & 20 \\
\hline 1981 & 76 & 71 & 5.5 & 0.5 & 2.1 \\
\hline 1982 & 97 & 92 & 80 & 0.5 & 17 \\
\hline 1983 & 96 & 92 & 82 & 04 & 14 \\
\hline 1984 & 76 & 72 & 59 & 0.8 & 1,6 \\
\hline 1985 & $1 \%$ & $10 \%$ & 56 & 02 & 1,6 \\
\hline 1086 & 70 & 68 & 56 & 0.2 & 144 \\
\hline 1987 & 62 & 6. & 50 & 01 & 12 \\
\hline
\end{tabular}

Calculated using average of labor lorce composition in 1956 and 198 \% (see table 2).

Table 4 summarizes various unemployment rates and provides information about how the changing composition of the labor force influences the overall unemployment rate. A comparison of the alternative rates with the overall rate shows that demographic shifts were most pronounced in the 1956-79 period, Changes in the composition of the labor force shifted the unemployment rate upward by 0.8 percentage points loverall less fixed-weight column' compared with an actual rise of 1.8 percentage points 15.9 minus 4.1$)$. In other words, the labor market pressure of 4.1 percent in 1956 would have changed to 4.9 percent in 1979 because of a shift in the composition of the labor force toward the youngest groups.

There was also a widening of the difference between the overall unemployment rate and that for prime-age males, reaching 2.5 percentage points in 1979 , up from 1.2 percentage points in 1956. This differential yields the same general conclusion: considering demographic changes, the natural rate of unemployment rose quite shaply between 1956 and 1979 .

Since 1979, the composition of the labor force has shifted back toward the older groups, which suggests that the natural rate of unemployment has declined. The difference between the fixedweight measure and the overall rate has narrowed to almost zero. The smaller differential means that demographic considerations no longer loom as large in determining if the economy is at full employment. For demographic reasons alone, the 1987 natural rate of unemployment is only about 0.3 percentage points higher than that of 1956 , and 0.5 percentage points lower than that of 1979 . This interpretation is supported by the change in the differential between the overall rate and that for prime-age males. Thus, although methods vary in calculating the effects of changing demographics on the unemployment rate, there seems to be little doubt that changes in the composition of the labor force since 1979 have produced a lower natural rate of unemployment. ${ }^{\text {}}$

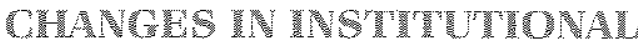 HCWORS}

As noted earlier, in addition to the age-sex composition of the labor force, many other factors infuence the unemployment rate. These factors are discussed in this section along with a summary of their recent trends.

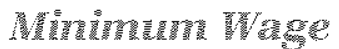

Federal minimum wage legislation was introduced in the United States in 1938; by 1985,80 percent of the U.S. labor force was employed in sectors subject to its coverage. By paying the lowest-income workers a higher wage than the competitive market would pay in the absence of a 


\section{Chart 3}

\section{Minimum Wage}

\section{as a Percent of Average Hourly Earnings}

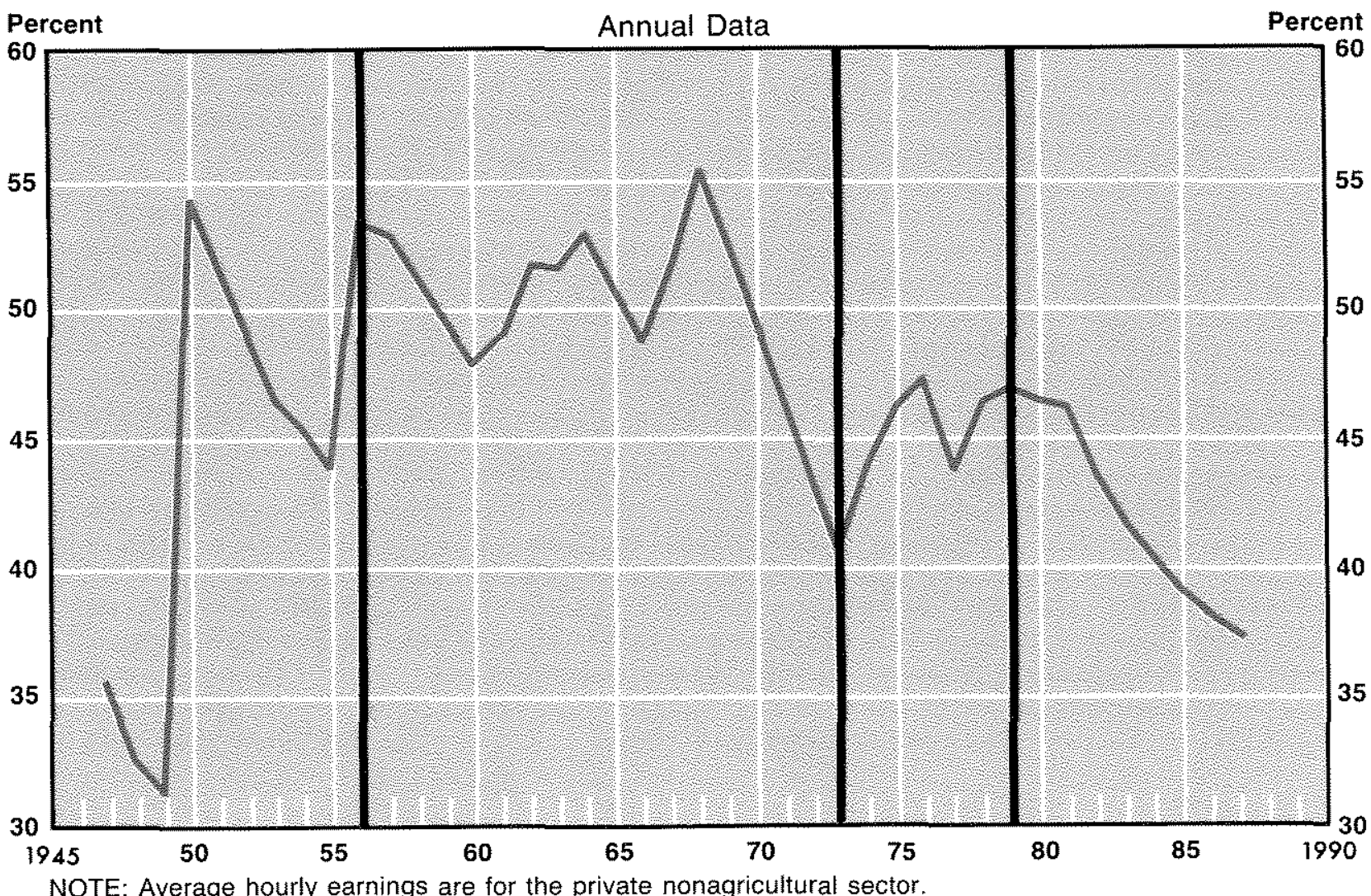

minimum wage, this legislation rased the average level of real wages above their competitive level." In response, the quantity of labor services supplied will exceed the quantity demanded, with the difference being classified as unemployed.

When the minimum wage was first legislated in 1938 , it was $\$ .25$ per hour and covered about 40 percent of the nation's nonsupervisory employees. Over the $1938-81$ period it was raised 15 times, reaching $\$ 3.35$ per hour in 1981 and has not been changed since. By 1985, 87 percent of nonsupervi sory employees were subject to the minimum wage.

The minimum wage law has had its greatest effect on teenage employment with little effect on other age groups. Because they have fewer skils and less education, teenagers' marginal products are typically below those of older, more experi- enced workers. Consequently, the minimum wage is much more kikely to be above the competitive wage for this group.

To assess the impact of minimum wage legislation, the minimum wage must be viewed relative to average hourly eamings. The comparison measure used here is aveage hourly earnings for workers in the private nonigricultural secto:" The thovement of the minimum wage relative to this measure from 1947 to 1987 is shown in chart 3

After a lange jump in 1950 , the mintrum wage relative to average hourly earnings fuctuated between 45 percent and 55 percent, before dropping below 45 percent in 1972 , It then rose from aboul 40 percent in 1973 to 46 percent in 1981 . With the minimum wage constant at 83.35 per hour since 1981, however, a steady decline in the relative

"For a survey, see Brown, Gilroy and Kohen (1982). 


\section{Chart 4 Replacement Ratio and Unemployment Rate}

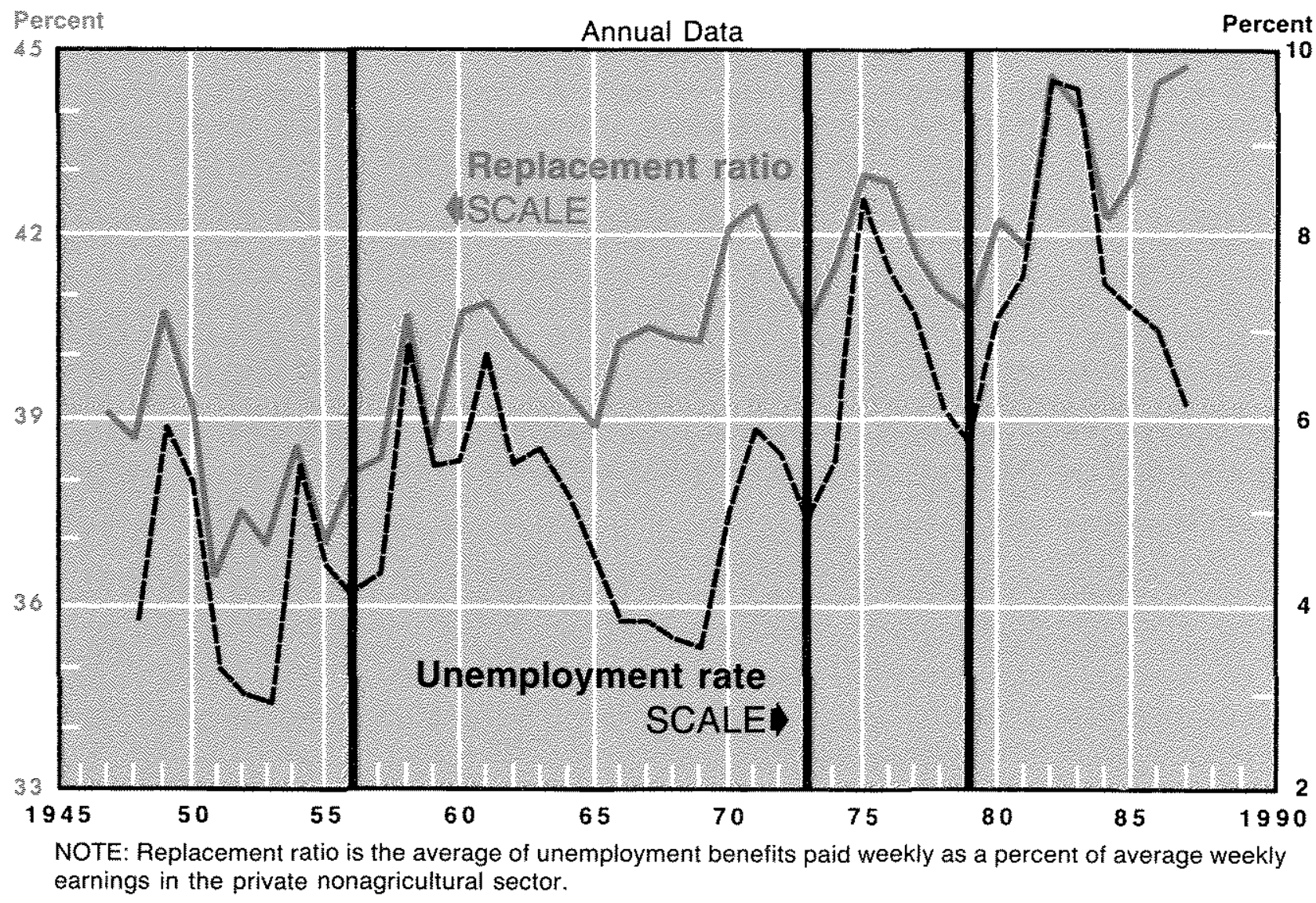

minimum wage has occurred since then, reaching 37 percent in 1987 .

Although the relative minimum wage declined from 1957 to 1973 , the coverage increased from 45 percent to 75 percent, primarily because of the rapid growth of teenagers in the labor force. The minimum wage may have pushed the unemployment rate upward from 1973 to 1979 , but this trend was sharply reversed from 1979 to 1987 Since the last benchmark year of 1979 , the minimum wage movements have had a positive effect on the labor market; its decline has reduced the natural rate of unemployment.

\section{Unemplonmenthenefts}

An increase in unemployment benefits relative to wages lowers the cost of job search.$^{*}$ As a result, other things equal, individuals will search longer for a job, lowering the amount of work that they are willing to supply at a given real wage. Also, individuals who are not in the labor force will be inclined to enter it to obtain a job and be eligible for unemployment benefits in the future.

One important measure in assessing the effeet of unemployment benefits is the ratio of average unemployment benefits paid weekly relative to average weekly earnings. This ratio is called the replacement ratio. Chart 4 shows the ratio from 1947 to 1987 as a solid line. Because this ratio shows cyelical movement throughout the period, the unemployment rate is also charted ddashed linel.

Generally, the replacement ratio and the unemployment rate move in tandem. From 1965 to 1973 , 
however, the replacement ratio rose quite sharply relative to unemployment. From 1973 to 1979 , it then declined slightly relative to the unemployment rate. But since 1984 , the divergence between these measures has been sharp.

A closer examination reveals that the source of this recent divergence is chiefly a slowing of average weekly earnings while unemployment benefits have continued to rise at relatively rapid rates. Despite this development, the replacement ratio seems to have had a recent upward effect on the natural rate of unemployment. This effect is dampened somewhat by two considerations: (1) recent changes in tax law whereby unemployment benefits became partially subject to taxation in 1979, and completely so in 1987, and (2) a general tightening of eligibility requirements in recent years. ${ }^{3}$ 'Thus, the actual value of the replacement ratio in 1987 relative to 1979 is less than shown in the chart. It is impossible, however, to say how much the change is without further research.

\section{Tages}

Another factor of considerable importance in determining unemployment trends is the role of taxes in influencing the labor markets." Again, the analysis is complex and the conclusions are not clear-cut. As an aid in understanding the macroeconomic effects, it is useful to think in terms of the effects on labor supply and demand separately.

Focusing first on labor supply, the tax wedge is the difference between the real wage that the employer is willing to pay and the after-tax value of that wage to the workers; the size of this wedge is important in the work-vs.-leisure decision that people make. An increase in the tax wedge will reduce labor services offered at a given real wage and may encourage a longer job-search by reducing the cost of being unemployed.

On the cemand side of the labor market, the relevant tax is the employer's contribution for ${ }^{2}$ social insurance. Introducing (or raising) this tax reduces the quantity of labor demanded for a given real wage and, because of the higher cost of labor, may also lengthen the amount of time employers take in searching for workers.

Thus, increased tax rates, whether applicable to employers or employees, reduce employment and may increase unemployment. To show what has happened to the tax wedge, employee and employer taxes are combined into a summary measure and plotted against the unemployment rate in chart 5 . This tax wedge measure incorporates personal income taxes (federal, state and local, employer and employee contributions for social insurance, and sales and excise taxes. ${ }^{3.5}$ Using 1956 as a reference point, the tax wedge has increased from about 21 percent to more than 32 percent by 1987. The rise was relatively rapid from 1956 to 1973 , slightly slower from 1973 to 1979 and even slower from 1979 to 1987 . These trends suggest that taxes contributed to an increase in unemploy. ment before 1979 ; since then, the tax wedge has had little effect, except perhaps to reduce unemployment somewhat since 1981 .

\section{Demand Shin}

Recent research has suggested that shifts in industry demand also have an effect on the naturat rate. ${ }^{36}$ This effect is commonly called frictional unemployment. If changing tastes, technology or relative factor prices induce rapid shifts in industry demands for labor, there will be greater unce:tainty in labor markets and increased search time for both the employee and the employer.

Unemployment that occurs for these reasons is a healthy meflection of a dynamic economy. For our discussion, however, only the long-run movements in the composition of industrial output are relevant. Chart 6 is one attempt to capture this phenomenon; it shows the three-year moving average of the sum of the absolute percentage
${ }^{13}$ See Abraham (1988) and, for a state-by-state summany of unemployment legislation in 1987, see Rumner (1988).

${ }^{14}$ Meyer (1981).

15The tax wedge for households (or suppliers of labor services) is

$$
\frac{W}{P}-\frac{W}{P} \frac{\left(1-t_{p}\right)}{\left(1+t_{c}\right)}
$$

where $W$ is the nominal wage, $P$ is the price level, $t_{p}$ is the personal tax rate and $t_{c}$ is the consumption tax rate. This expression can be manipulated to give

$$
\frac{W}{P} \frac{\left(t_{c}+b_{b}\right)}{\left(1+t_{c}\right)}
$$

Chart 4 shows the value of the expression following W/P plus the employer's contribution rate for social insurance. For further discussion, see Parkin (1984), pp. 184-85.

${ }_{16}^{16}$ For a discussion and critique of this literature, see Johnson and Layard (1986). See also Litien (1982), Litien and Hall (1986), and Pissman (1986). 
Chart 5

Estimate of Tax Wedge and Unemployment Rate

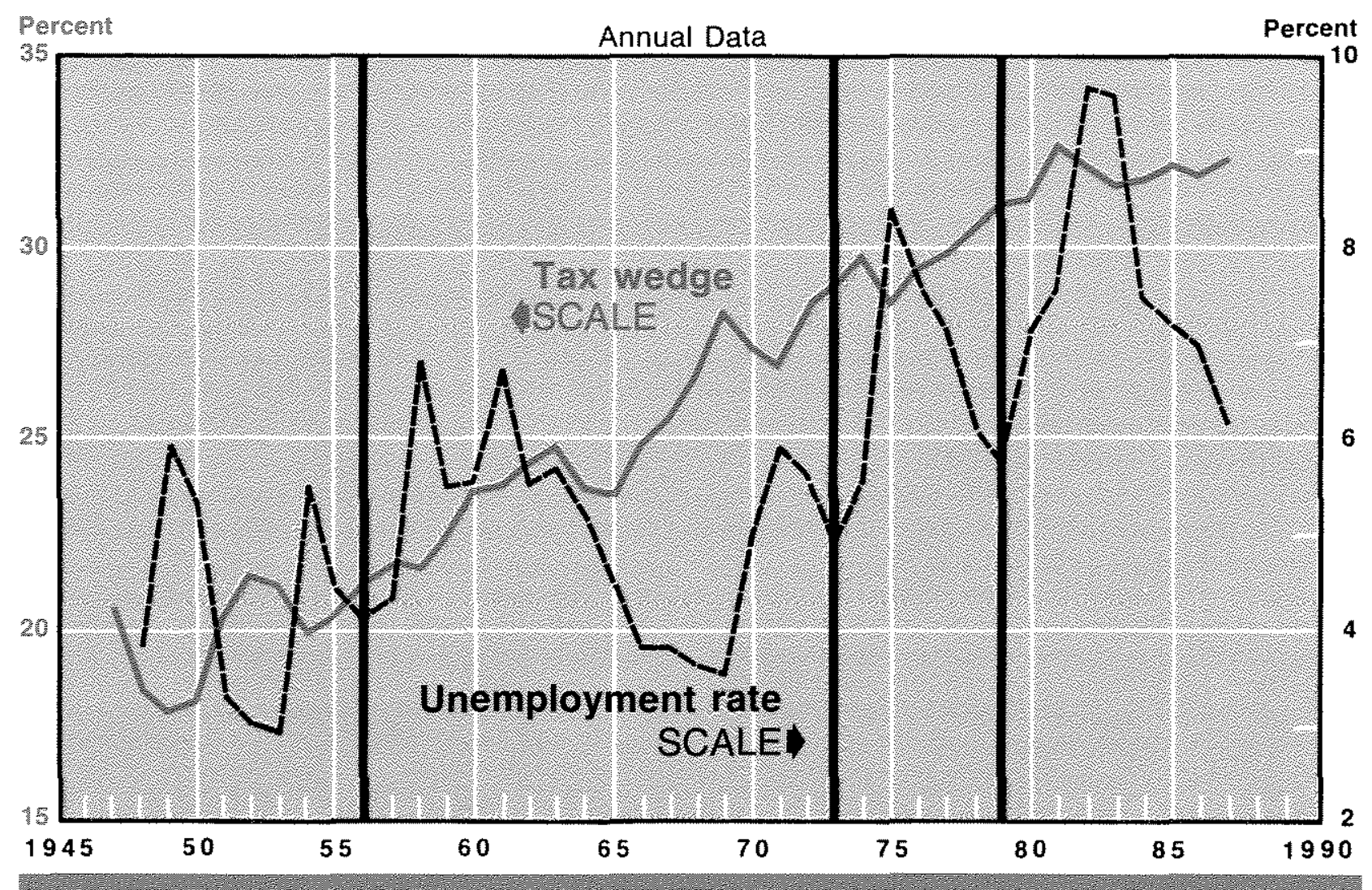

change in sectoral employment shares. ${ }^{17}$ By this measure, there was a downward trend in the degree of shifting employment until the mid-1960s; since then the measure of shifting employment has moved upward, although it has varied substantially around the trend.

Focusing on the benchmark years, there is a slight downward movement from 1956 to 1973 to 1979, followed by an upward movement from 1979 to 1987 . From 1982 to 1987 , however, the measure dropped sharply." Viewed in this perspective, it is unlikely that shifts in the structure of the economy have influenced the natural rate of unemployment substantially. The relationship between "demand" shifts and the unemployment rate appears, rather, to be a shorter-run phenomenon.

\section{Oher Fachors}

The above list of factors, while not exhaustive, summarizes most of the factors that influence unemployment trends. Government regulations, however, also affect labor markets. For example,
${ }^{17}$ The measure of demand shift (in year $t$ ) is

$$
100 \times\left[\sum_{i=1}^{10}\left|\frac{E_{i, t}}{E_{i}}-\frac{E_{i, t, 1}}{E_{i, \ldots 1}}\right|\right] .
$$

where $E_{j, 8}$ is employment in the ith industry in year $t$ and $E_{\text {; }}$ is total employment in year . Data used were employees on nonagricultural payrolls by major industry. See Council of Economic Advisers (1988), pp. 296-97.

${ }^{15}$ One factor operating during this period was the sharp swing in the value of the dollar, rising sharply from 1980 to 1985 , and then falling sharply to 1987 . If these developments affected mainly manufacturing exports, the effect could have been to raise frictional unemployment (and the natural rate) when the dollar was rising, and lower such unemployment when it was falling. But since the focus here is on $1987 \mathrm{vs.} 1979$, a period over which the vade-weighted exchange rate rose only 10 percent, there would seem to be little net effect on the naturat rate. Furthermore, manufacturing employment as a percent of total non-agricultural employment has shown little sensitivity to exchange rate movements, even of the magnitude experienced in the 1980s. 


\section{Chart 6 \\ Measure of Demand Shift and Unemployment Rate}

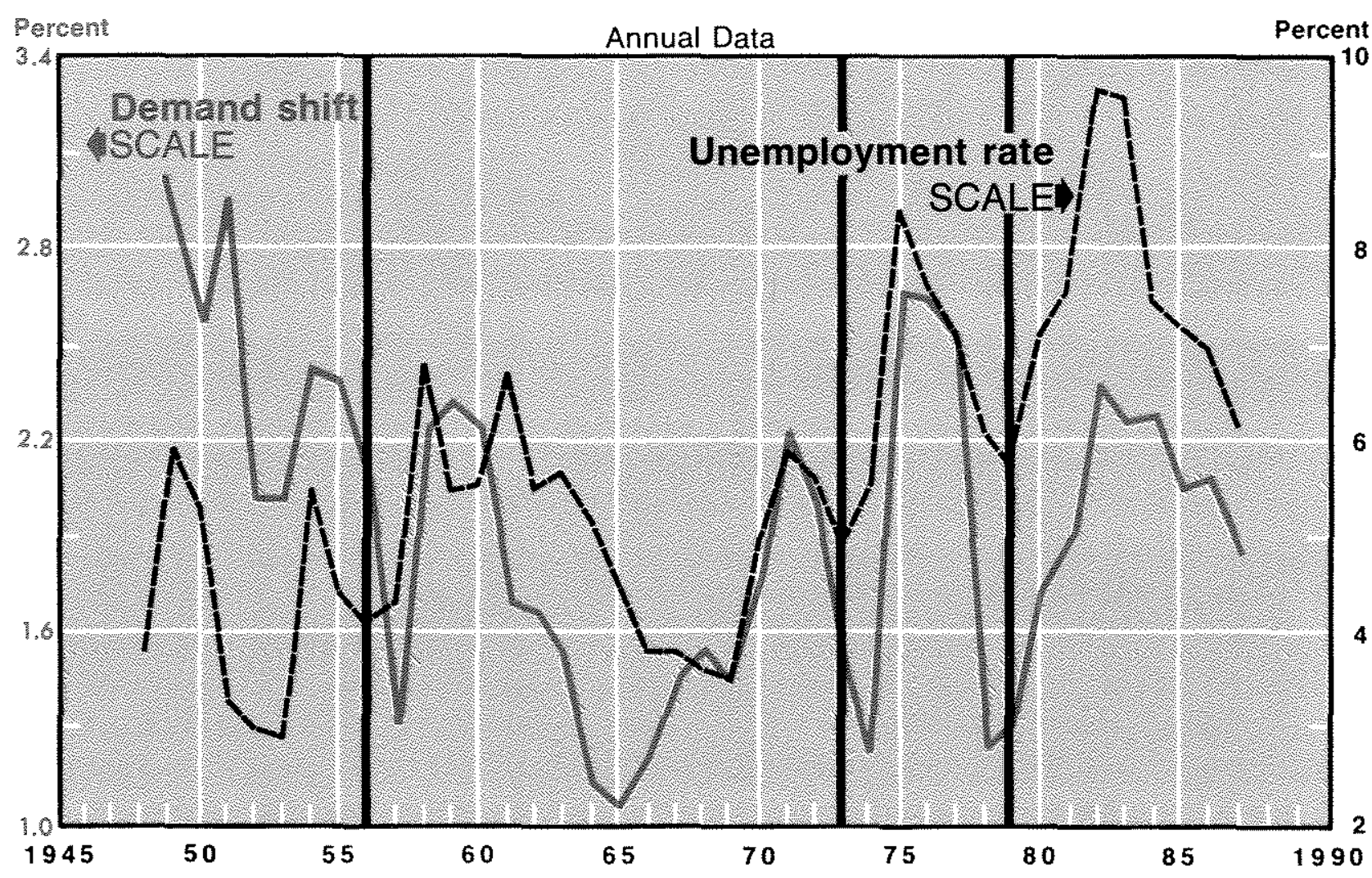

regulations imposed by the Occupational Safety and Health Administration (OSHA) in the interest of safety and health can divert funds that would nomally be used for investment spending." These regulations can act like an employer tax, driving a wedge between the wage the employer is willing to pay and the actual cost.

Another example of regulations that had an important effect on unemployment are work registration requirements for various govemment programs like welfare and food stamps. For example in 1972, legislation was passed that required welfare mothers who were able to work to register for work ${ }^{23}$ Although some found jobs, others were added to the count of the unemployed.

\section{SUMNARV OR TATOPS APTECMUG

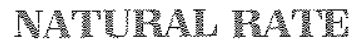

The role of these factors is brought together in table 5. Shown are general conclusions about the direction in which the structural factors have been operating between the benchmark years since 1956. No attempt is made to estimate precisely the magnitude of the effects on the natural rate of unemployment.

The most obvious change in recent years is the shifting age distribution of the labor force, which has reduced the unemployment rate. In other words, the baby boomers, who made their pres" ence felt throughout the 1970 s by pushing up the natural rate of unemployment, are now in the prime-age group. Having accumulated skils, edum cation and experience, this group is now marketing its productive skills, thus reducing the natural rate of unemployment by about one-half of a percentage point from 1979 .

The minimum wage has had a favorable effect in reducing the trend of unemployment since 1981 , but no attempt was made here to estimate the magnitude of effect. Cagan, however, estimated 


\section{Table 5}

\section{Summary of Etfects on the Natural Rate of Unemployment}

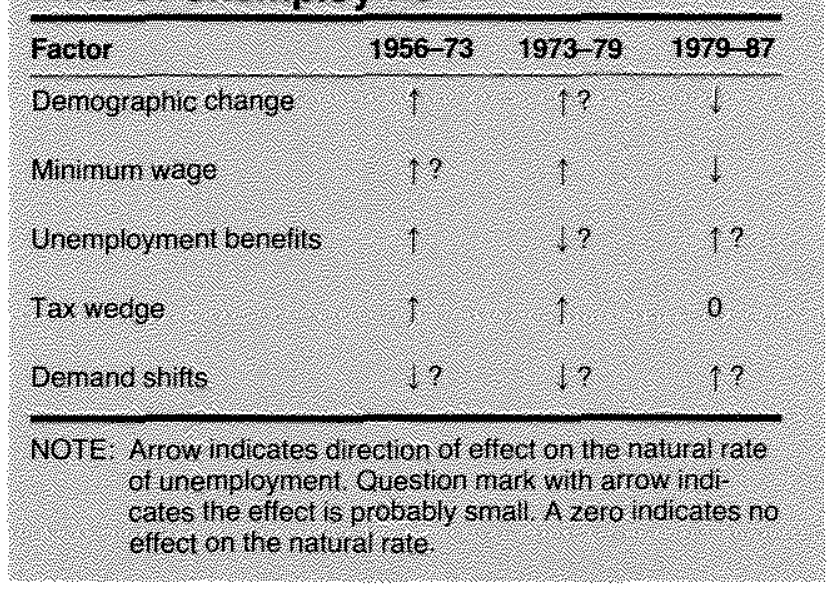

that the minimum wage contributed to an increase in the natural rate of 45 percentage points from 1956 to $1977 . "$ The relative minimum wage in 1987 was below that in 1956 . With the decline in the proportion of teenagers in the labor force, however, the magnitude of the effect on the natural rate of unemployment is probably less than Cagan estimated.

Unemployment benefits generally appear to have affected recent unemployment trends negatively. The replacement ratio has risen quite dramatically since 1984. This is misleading, however, because starting in 1987, unemployment benefits became fully taxable by the federal government, while eligibility requirements have been tightened in recent years. These developments have raised the cost of being unemployed and have reduced the trend of umemployment.

Taxes were a factor in the $1956-73$ petiod land to some extent from 1973 to 1979 ), increasing un employment, both by reducing the cost of the job search (reducing foregone earnings) and increasing the tax wedge between what employers pay to labor and workers receive. Since 1979, however, the upward trend of taxes has slowed, suggesting that the tax wedge has not worsened. These developments are assessed as having no effect on the natural rate in the $1979-87$ period.

Despite considerable fluctuation in the shares of sector employment, demand-shift factors do not appear to have been a factor during the post-
World War If period. In genemal, the key factors that influence the natual rate of unemployment have served to reduce it in the $1980 \mathrm{~s}$. As a result, the cument natural rate appears below the 6 percent rate estimated in $1979 \%$ Shilts in the age structure of the labor force alone have reduced it about one-hall of a percentage point. Other favorable developments, as noted in table 5, may have reduced it even further.

\section{SUMMNAR}

Unemployment rates below 6 percent in late 1987 and early 1988 have raised questions about how far the rate can fall before inflation again emerges. The fact that inflation has shown no clear signs of acceleration suggests that structural changes in the U.S. economy have reduced the natural rate of unemployment below what it was in 1979 . This article examined some of these structural factors.

Several of these factors were found to have reduced the natural rate of unemployment in recent years, when compared with previous experience from 1956 to 1979 . The age composition of the labor force, the minimum wage, individual and employer tax mates are a few of the factors that have moved favorably. Any conclusions about unemployment benefit ratios, however, require further study. For the unemployment rate to continue to decline depends critically on the course of future government actions, namely, legislation relating to the minimum wage, tax rates and unemployment benefits.

\section{RERPRENGES}

Abraham, Katharine G. "Has the Natural Rate of Unemployment Fallen?" mimeo (University of Maryland, June 1988),

Antos, Joseph, Westey Mellow, and Jack E. Triplett. "What is a Current Equivalent to Unemployment Rates of the Past?" Monthly Labor Review (March 1979), pp. 36-46.

Brown, Charles, Curtss Gilroy and Andrew Kohen. "The Effect of the Minimum Wage on Employment and Unemployment," Joumal of Economic Literature (June 1982), pp. $487-528$.

Bureau of Labor Statistics. How the Government Measures Unemployment, Report 742 (U.S. Government Printing Office, September 1987).

Cagan, Phillip. Persistent Inflation: Historical and Policy Essays (Columbia University Press, 1979).

Cain, Glen G. "The Unemployment Rate as an Economic Indicator," Monthly Labor Review (March 1979), pp. 24-35. 
Clark, Peter K. "A New Estimate of Potential GNP," The 1977 Economic Peport of the President, Hearings before the Join: Economic Committee, Congress of the United States, Part 1 (GPO, 1977), pp. 39-55.

Clarkson, Kenneth W. and Roger E. Meiners. Inflated Unemployment Statistics: The Effects of Welfare Work Registration Requirements (University of Miami School of Law, March 1977).

Council of Economic Advisers. Economic Report of the President (GPO, 1978).

. Economic Report of the President (GPO, 1988).

de Leeuw, Frank, and Thomas M. Holloway. "Cyclical Adiustment of the Federal Budges and Federal Debt," Survey of Current Business (December 1983), pp. 25-40.

Flaim, Paul $O$. "The Effect of Demographic Changes on the Nation's Unemployment Rate, "Monthly Labor Review (March 1979), pp. 13-23.

Gordon, Robert J. Macroeconomics, 4th ed. (Little, Brown and Co., 1987).

. "The Role of Wages in the Intlation Process," American Economic Review, Papers and Proceedings (May 1988), pp. 276-83.

Johnson, G. E., and P. R. G. Layard. "The Natural Rate of Unemployment: Explanation and Policy," in Orley Ashenfetter and Richard Layard, eds., Handbook of Labor Economics, vol. II (North-Holiand, 1986), pp. 921-99.

Licht, Walter. "How the Workplace has Changed in 75 Years," Monthy Labor Review (February 1988), pp. 19-25.
Lillen, David M. "Sectoral Shits and Cycical Unemployment," Joumal of Political Economy (August 1982), pp. 777-93.

Lilien, David M., and Robert E. Hail. "Cyclical Fluctuations in the Labor Market," in Orley Ashenfelter and Fichard Layard, eds. Handbook of Labor Economics, vol. 11 (North-Holland, 1986), pp. $1001-35$.

Meyer, Laurence H., ed. The Supply-Side Effects of Economic Policy, Proceedings of a Conference cosponsored by Wash. ington Universisy in St. Louis and Federal Reserve Bank of St Louis, October 24-25, 1980 (May 1981).

Office of Management and Budget. Budget of the United States Government: Fiscal Year 1989 (GPO 1988)

Parkin, Michael. Macroeconomics (Prertice-Hal, 1984).

Rissman, Ellen R. "What is the Natural Rate of Unemployment?" Federal Reserve Bank of Chicago Economic Perspectives (September/October 1986), pp. 3-17.

Runner, Diana. "Changes in Unemployment Insurance Legislation During 1987," Monthly Labor Review (March 1988), pp. $9-16$

Santomero, Anthony M., and John J. Seater. "The hiflationUnemployment Trade-Off: A Critique of the Literature," Journal of Economic Literature (June 1978), pp. 499-544.

Shank, Susan E. "Women and the Labor Market: The Link Grows Stronger," Monthly Labor Review (March 1988), pp. $3-8$.

Weiner, Stuart E. "The Natural Rate of Unemploymen: Concepts and Issues," Federal Reserve Bark of Kansas City Economic Review (January 1986), pp. 11-24. 